\title{
DATA TO THE MALAYSIAN LIVERWORT FLORA, I
}

\author{
Tamás Pócs ${ }^{1}$, Haji Mohamed, Kien-Thai Yong \& Yih-Horng Cheah
}

\begin{abstract}
Malaysia for oil body studies belonged to 80 species, 6 of which (Frullania subocellata S. Hatt., Chiloscyphus integerrimus Schiffn., Bazzania assamica (Steph.) S. Hatt., Bazzania bilobata Kitag., Telaranea quadriseta (Steph.) J. Engel \& G. L. Merrill and Radula assamica Steph.) proved to be new for Malaysia and 9 to its peninsular part or to Selangor or Pahang states. The most interesting occurrences were of Frullania subocellata, hitherto known only from Seram Island, Chiloscyphus integerrimus, known from Java, and Telaranea quadriseta, an Australian element. The majority of the collected species are of Indomalesian distribution. Microphotos and distribution maps of the more interesting species are provided.
\end{abstract}

Key words: Frullania, Indomalaya, Lejeuneaceae, Lepidoziaceae, Pahang, Selangor

Tamás Pócs, Department of Botany, Institute of Biology, Eszterházy Károly College, H-3301 Eger, Pf. 43, Hungary; e-mail: colura@upcmail.hu

Haji Mohamed, Institute for Biodiversity and Environmental Research, University Brunei, Darussalam

Kien-Thai Yong \& Yih-Horng Cheah, Institute of Biological Sciences, Faculty of Science, University of Malaya, 50603 Kuala Lumpur, Malaysia

\section{INTRODUCTION}

A.M. Haji Mohamed, who at the time of the beginning of this research was Professor at the University of Malaya, initiated a project to investigate the oil bodies of Malaysian liverworts. As a result, in 2006 K.-Th. Yong and P.-S. Cheah collected more than a hundred specimens of Malaysian liverworts and prepared microphotos of their habit and oil bodies at the Institute of Biological Sciences. The material was sent to T. Pócs to identify the species and their oil body types. During the identification work the collected material proved to belong to 80 liverwort species, 6 of which are new for Malaysia and a further 9 new for the whole of peninsular Malaysia or to Selangor or Pahang states according to the checklists of Chuah-Petiot (2011) and Lee et al. (2013). Most species are Indomalesian in distribution. A few of them, which belong to critical and recently revised groups, show a very disjunct distribution pattern. These elements may be rare

\footnotetext{
1 Corresponding author
}

or even more widespread but only overlooked or lying unidentified in herbaria. Such species are Chiloscyphus integerrimus, Frullania subocellata and Telaranea quadriseta. Here we enumerate these species with their new localities and worldwide distribution. The results of oil body studies will be published separately. Voucher specimens are deposited in the herbarium of the University of Malaya (KLU), and duplicates in the herbarium of Eszterházy College in Eger (EGR).

\section{ENUMERATION OF SPECIES}

FRULLANIACEAE

Frullania subocellata S. Hatt. Figs 1B \& 3

SPecimens examined: PAhang, Cameron Highland, Tanah Rata, vicinity of Cool Point Hotel, 1400 m, Cheah \& Yong 31, 26 Aug. 2006.

Distribution. New for Malaysia, previously known only from Seram Island, Indonesia (Hattori 1986). 


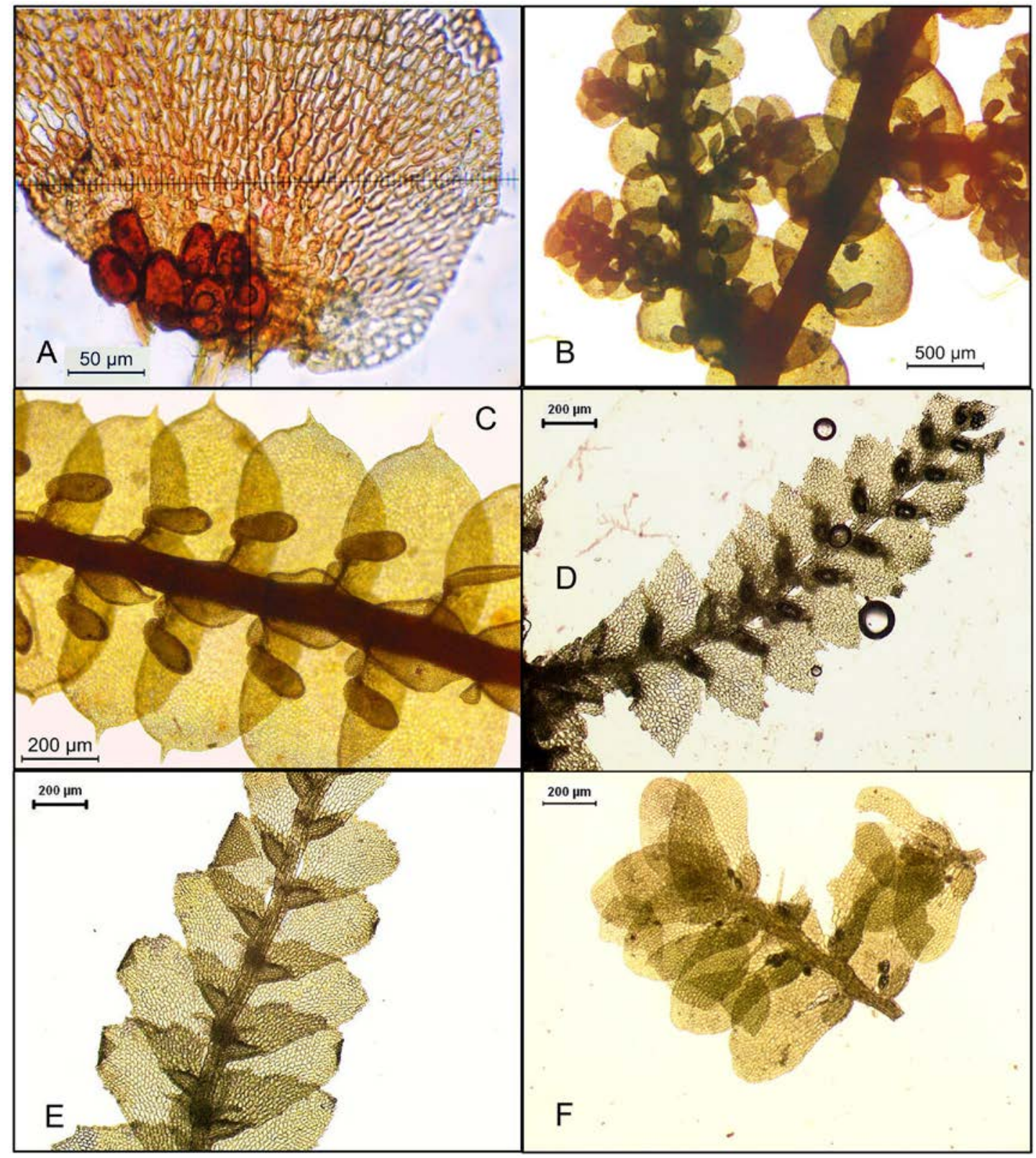

Fig. 1. A \& C - Frullania trichodes Mitt., B - Frullania subocellata S. Hatt., D - Drepanolejeunea fissicornua Steph., E - Drepanolejeunea levicornua Steph., F - Drepanolejeunea spicata (Steph.) Grolle. Microphotos by T. Pócs (A) and K.-T. Yong (B-F). 


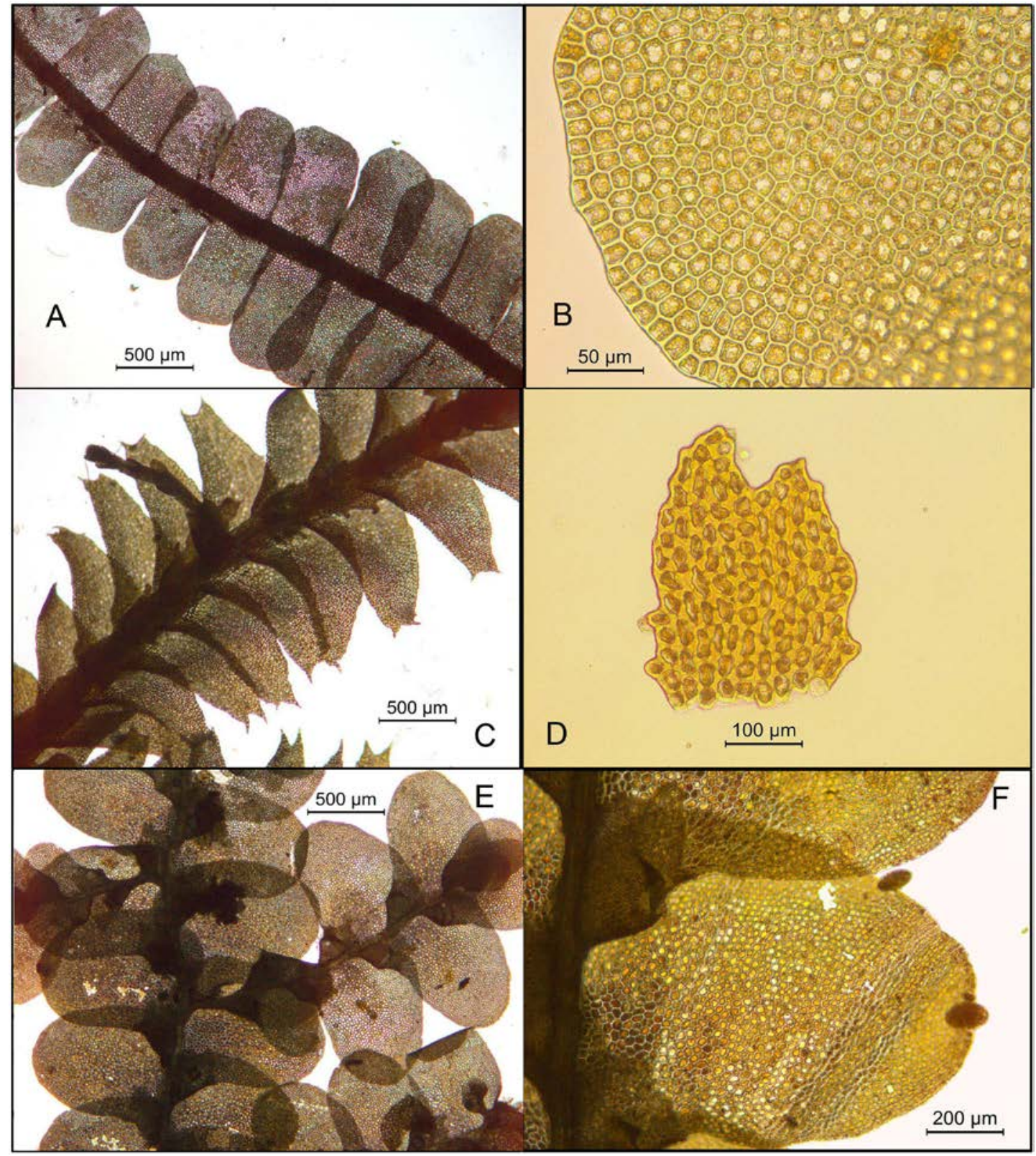

Fig. 2. A \& B - Chiloscyphus integerrimus Schiffn., C \& D - Bazzania bilobata Kitag. E \& F - Radula assamica Steph. Microphotos by K.-T. Yong. 


\section{Frullania trichodes Mitt.}

Fig. 1A, C

F. vethii Sande Lac.

Specimens examined: Pahang, Genting Highland, along the road to Gohtong Jaya, roadside vegetation, 830 m, Cheah \& Yong 4, 22 July 2006.

Distribution. New for peninsular Malaysia, known from Sarawak and Sabah. Widespread Indomalayan-Pacific species (Chuah-Petiot 2011; Hattori \& Piippo 1986).

\section{GEOCALYCACEAE}

Chiloscyphus integerrimus Schiffn.

Figs 2A, B \& 3

Specimens examined: Selangor, Ulu Selangor, Fraser's Hill, 1220 m, Cheah \& Yong 99, 1 Dec. 2006.

Distribution. New for Malaysia, previously known only from Java (Schiffner 1900).

\section{LEJEUNEACEAE}

Cololejeunea hillebrandii (Aust.) Steph.

Specimens examined: Selangor, Ulu Selangor, Fraser's Hill, 1220 m, Cheah \& Yong 109c, 1 Dec. 2006.

Distribution. New for Selangor state, in Malaysia known from Penang, Perak and Pahang states. Pantropical (Pócs \& Piippo 2011).

Drepanolejeunea fissicornua Steph. Fig. 1D

Specimens examined: Selangor, Ulu Selangor, Fraser's Hill, 1220 m, Cheah \& Yong106, 1 Dec. 2006.

DisTRIBUTION. New for peninsular Malaysia, known from Mt. Kinabalu in Sabah state, and from Sumatra and Java in Indonesia (Mizutani 1990).

\section{Drepanolejeunea levicornua Steph. Fig. 1E}

Specimens examined: Selangor, Ulu Selangor, Fraser's Hill, 1220 m, Cheah \& Yong 100, 1 Dec. 2006.

Distribution: New for Selangor state, known from Pahang in Malaysia, from Sulawesi, Kalimantan and Seram in Indonesia, and from Papua New Guinea (Mizutani 1990).
Drepanolejeunea pentadactyla (Mont.) Steph.

Specimens examined: Selangor, Ulu Selangor, Fraser's Hill, 1220 m, Cheah \& Yong 109b, 1 Dec. 2006.

Distribution: New for Selangor state, in Malaysia known from Kedah, Malacca, Johore, Pahang, Sabah and Sarawak (Chuah-Petiot 2011; Lee et al. 2013). Widespread Indomalesian-Pacific species (Zhu \& So 2001; Dey \& Singh 2012).

\section{Drepanolejeunea spicata (Steph.) Grolle}

Specimens examined: Pahang, Genting Highland, along the road to Gohtong Jaya, roadside vegetation, 820 m, Cheah \& Yong 61, 9 Sept. 2006.

Distribution. New for peninsular Malaysia, known from Sarawak and Sabah states (ChuahPetiot 2011), outside Malaysia from Eastern Himalaya and Sumatra through Thailand, Cambodia, Laos, Vietnam to southern China and the Ryukyu Islands in Japan (Grolle \& Zhu 2000).

\section{Drepanolejeunea tricornua Herz.}

Specimens examined: Pahang, Genting Highland, along the road to Gohtong Jaya, roadside vegetation, $820 \mathrm{~m}$, Cheah \& Yong 54, 57b, 9 Sept. 2006; Selangor, Ulu Selangor, Fraser's Hill, 1220 m, Cheah \& Yong 107, 1 Dec. 2006.

Distribution. New for peninsular Malaysia. Known from Sarawak and Sabah states in Malaysia and from Java, Seram and Papua New Guinea (Mizutani 1990).

\section{Lejeunea dimorpha Kodama.}

Specimens examined: Selangor, Ulu Selangor, Fraser's Hill, 1220 m, Cheah \& Yong 103, 1 Dec. 2006.

Distribution. New for Selangor state, known from Kelantan, Pahang and Sabah states, outside Malaysia from Kalimantan and Papua New Guinea (Lee 2013).

\section{Lejeunea micholitzii Mizut.}

Specimens examined: Selangor, Ulu Selangor, Fraser's Hill, 1220 m, Cheah \& Yong 104, 1 Dec. 2006. 


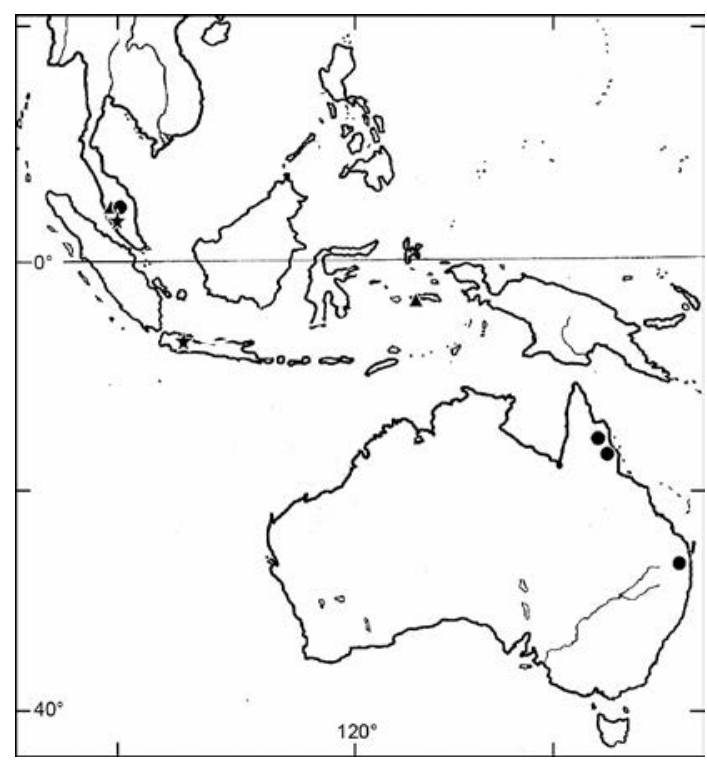

Fig. 3. Distribution of some disjunct species. $\boldsymbol{\Delta}$ - Frullania subocellata $\mathrm{S}$. Hatt., $\star-$ Chiloscyphus integerrimus Schiffn., - - Telaranea quadriseta (Steph.) J. Engel \& G. L. Merrill. Drawn by T. Pócs.

Distribution. New for Selangor state, known from Kelantan, Pulau Langkawi, Negeri Sembilan, Pahang and Sabah, outside Malaysia from Java, Sumatra, Philippines, New Guinea and Fiji Islands (Lee 2013; Grolle \& Piippo 1984; Hürlimann 1993).

\section{LEPIDOZIACEAE}

Bazzania assamica (Steph.) S. Hatt.

Bazzania tridens (Reinw. et al.) Trev. var. assamica Pócs

Specimens examined: Pahang, Genting Highland, along the road to Gohtong Jaya, roadside vegetation, 820 m, Cheah \& Yong 42c, 9 Sept. 2006.

Distribution. New for Malaysia, known from Eastern Himalaya, Myanmar and Vietnam (Pócs 1969).

Note. According to Sharma and Srivastava (1993), B. assamica is an independent species distributed from Himalaya to Vietnam, while $B$. tridens is a very widespread Indomalayan element.
Bazzania bilobata Kitag.

Figs 2C, D

SPecimens examined: PAhang, Cameron Highland, Brinchang, along the trail to Mount Irau, $1800 \mathrm{~m}$. Cheah \& Yong 6a, 26 Aug. 2006.

Distribution. New for Malaysia, previously known from its type locality in northern Thailand (Kitagawa 1967) and from southern China (Guangxi: Zhu \& So 2003; Fujian, Guangdong and Jiangxi: Zhou et al. 2012).

Telaranea quadriseta (Steph.) J. Engel \& G. L. Merrill

Fig. 3

Specimens examined: Pahang, Genting Highland, along the road to Gohtong Jaya, roadside vegetation, 820 m, Cheah \& Yong 42b, 9 Sept. 2006.

DisTRIBUTION. New for Malaysia, previously known only from tropical and subtropical Australia: Queensland and New South Wales (Engel \& Merrill 2004).

\section{RADULACEAE}

Radula assamica Steph.

Fig. 2E, F

Specimens eXamined: Pahang, Genting Highland, along the road to Gohtong Jaya, roadside vegetation, $820 \mathrm{~m}$, Cheah \& Yong 42b, 9 Sept. 2006; Selangor, Ulu Selangor, Fraser's Hill, 1220 m, Cheah \& Yong 66 \& 101, 9 Sept. and 1 Dec. 2006.

Distribution. New for Malaysia. A Himalayan-Indochinese species known from Sri Lanka and India: Assam through Myanmar and Thailand to Vietnam and southern China (Yamada 1979). Radula assamica can therefore be considered a typical Himalayan-Indochinese subendemic element.

Acknowledgements. We are grateful to Professor S. Robbert Gradstein (PC) and Dr. Gaik Ee Lee (LMU) for their useful advice and amendments to the manuscript.

\section{REFERENCES}

Chunh-Petiot M. S. 2011. A checklist of Hepaticae and Anthocerotae of Malaysia. Polish Bot. J. 56(1): 1-44.

Dey M. \& Singh D. K. 2012. Epiphyllous liverworts of Eastern Himalaya. Botanical Survey of India, Kolkata. 
Engel J. J. \& Merrill G. L. S. 2004. Austral Hepaticae 35. A taxonomic and phylogenetic study of Telaranea (Lepidoziaceae), with a monograph of the genus in temperate Australasia and commentary on Extra-Australasian taxa. Fieldiana, Bot. n. ser. 44: 1-265.

Grolle R. \& PiIPPo S. 1984. Annotated catalogue of Western Melanesian bryophytes. I. Hepaticae and Anthocerotae. Acta Bot. Fenn. 125: 1-86.

Grolle R. \& Zhu R.-L. 2000. A study of Drepanolejeunea subg. Rhaphidolejeunea (Herzog) Grolle \& R.L. Zhu, stat. nov. (Hepaticae, Lejeuneaceae) in China with notes on its species elsewhere. Nova Hedwigia 70: 373-396.

Hattori S. 1986. Frullania collection made by Mr. H. Akiyama on Seram Island. J. Hattori Bot. Lab. 60: 239-253.

Hattori S. \& PiIPpo S. 1986. Bryophyte flora of Huon Peninsula, Papua New Guinea XV. Frullania (Frullaniaceae, Hepaticae). Acta Bot. Fenn. 133: 25-58.

Hürlimann H. 1993. Hepaticae aus dem Gebiete des südlichen Pazifik XII, die Gattung Lejeunea Libert. Bauhinia 11(1): 3-17.

Kitagawa N. 1967. Studies on the Hepaticae of Thailand I. The genus Bazzania, with general introduction. J. Hattori Bot. Lab. 30: 249-270.

LEE G. E. 2013. A systematic revision of the genus Lejeunea Lib. (Marchantiophyta: Lejeuneaceae) in Malaysia. Cryptog. Bryol. 34(4): 381-484.
Lee G. E., Gradstein S. R., Söderström L. \& Latiff A. 2013. Catalogue of the Lejeuneaceae of Malaysia. Malayan Nat. J. 65(2-3): 81-129.

Mizutani M. 1990. Notes on the Lejeuneaceae. 16. Drepanolejeunea thwaitesiana and its related species from Asia. $J$. Hattori Bot. Lab. 68: 367-380.

Pócs T. 1969. A short survey of the Bazzania of North VietNam. J. Hattori Bot. Lab. 32: 79-94 \& 204.

Pócs T. \& PiIPPo S. 2011. Bryophyte flora of the Huon Peninsula, Papua New Guinea. LXXIV. Cololejeunea (Lejeuneaceae, Hepaticae). Acta Bryolichen. Asiatica 4: 59-137.

SCHIFFner V. 1900. Die Hepaticae der Flora von Buitenzorg. I. E. J. Brill, Leiden.

Sharma D. \& Srivastava S. C. 1993. Indian Lepidoziinae. (A taxonomic revision). Bryophyt. Biblioth. 47: 1-353.

YAMADA K. 1979. A revision of Asian taxa of Radula, Hepaticae. J. Hattori Bot. Lab. 45: 201-322.

ZHU R.-L. \& So M. L. 2001. Epiphyllous liverworts of China. Nova Hedwigia Beih. 121: 1-418.

ZHU R.-L. \& So M. L. 2003. Liverworts and hornworts of Shangsi County of Guangxi (Kwangsi), with an updated checklist of the hepatic flora of Guangxi Province of China. Cryptog. Bryol. 24: 1-16.

Zhou L.-P., Zhang L. \& XING F-W. 2012. Taxonomical review of Bazzania (Lepidoziaceae, Marchantiophyta) in China. Journal of Fairylake Botanical Garden 11(2): 1-62. 